mended that all advisers be as well-prepared as possible for their positions. Nothing can destroy the effectivness of a council so much as over or under control. Proper guidance, whatever that may be for a particular school, must be maintained.

Training opportunities for student council members and sponsors alike are becoming more prevalent each year. The following are types of training which aid those involved with the council: (1) the National Association of Student Councils Annual Conference; (2) local, state, and national workshops; (3) state and regional conferences; and (4) leadership training within the school. Each of these features could be the topic for study.

There are a number of major points which seem to increase the value of student council activity for all concerned. I call these features the "theory of involvement." First, the work of the council must be necessary and meaningful. The projects undertaken must hold responsibility, must be a portion of total school articulation, and must serve some meaningful purpose. Second, the work of the council must encompass as much area as the principal can logically allot to it in light of the philosophy and regulations of the school. Third, the principal must have the courage to allow a council project to fail after all due assistance and guidance has been offered. Fourth, relationships between the council and the principal must be based upon mutual respect and confidence. A proposal by the council must receive serious consideration by the principal. On the other hand, the council must know that the basic precept of both the principal and its own body politic are identical-the welfare of the students who attend that school.

\title{
WHAT ARE CURRENT DEVELOPMENTS IN COLLEGE ADMISSIONS POLICIES?
}

Charrman: Russell H. Rupp, Principal, High School, Shaker Heights, Ohio.

\section{Discussants:}

B. A. Deist, Principal, High School, Glen Ridge, New Jersey.

George R. Champlin, Chief, Bureau of Elementary and Secondary Education, State Department of Education, Hartford, Connecticut.

\section{Summary of the presentation made by OLIVER W. MELCHIOR}

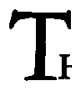

HE most significant current development in college admissions policies is the continued raising of standards of admission. Many colleges that have been able to admit all qualified applicants are finding that they

Oliver W. Melchior is Principal of Scarsdale High School, Scarsdale, New York. 
must now practice some selection among their candidates. The most selective institutions are having to reject well-qualified candidates.

These developments have naturally focused increasing attention on criteria for selection. Testing programs that are aimed at predicting the ability to succeed in college have grown markedly in volume. The significance and meaning of class rank in predicting success in college have been weighed and pondered. There is a growing interest in formulas that combine the data of selection to predict academic standing at the end of the first college year. Some institutions have doubted the wisdom of using a single prediction of general success in college and have experimented with differential predictions, that is, multiple predictions in several broad fields of knowledge.

While testing programs for admissions increase in scope, it is incumbent upon us in both schools and colleges to be properly careful of the ways in which these testing data are used. We must know what a test score tells and what it does not tell. There is a temptation to read more into a score than is there to read. Equally, class rank can be given a significance which it does not deserve. Selection must be made only after study of all available criteria and not by any easy process of cutting scores.

Scholarship testing programs have multiplied to the frustration of school and college officers and to the confusion of the candidates. Must the needless duplication in scholarship testing be further complicated before it becomes standardized, or can steps be taken now to coordinate these programs? The multiplication of testing dates and the interruption to classwork seem to be an unnecessary complication.

The public conscience is increasingly troubled by the large percentage of college freshmen failures. When we see as many as fifty per cent of a class flunking out, we are witnessing economic and personal tragedies which this nation can ill afford. Most of these cases can be avoided by enlightened policies and by improved counseling. The schools have an obligation to guide their students toward appropriate levels of postsecondary-school education. The colleges have an equal obligation to screen out the readily predictable failures and to guide applicants toward attainable goals.

As the academic quality of entering classes improves, the college admissions officers must share with their faculties the available descriptive data. There is considerable evidence that, although the quality of freshman classes is improving, the percentage of failures remains fairly constant. No one would argue against raising scholastic standards where they have been shoddy, but where standards have been sound it is sheer arrogance to flunk the borderline cases to promote a reputation for toughness. In established colleges of good reputation and quality, there is no legitimate reason for the college teachers to raise their levels of expectation as fast as the quality of their students improves. 
We have been talking about the borderline cases. As for the most able students, there are encouraging signs that teachers at both the school and college level are recognizing their responsibilities to stretch these eager young minds. The Advanced Placement Program has added a new dimension to secondary-school teaching and in ever-widening circles. There is a growing willingness on the part of sovereign college faculties to give credit for this work and to avoid the wasteful repetition in college of work already done soundly in high school. High-school administrators and college admissions officers are cooperating more closely to these ends and toward bringing together high-school teachers of seniors and college teachers of freshmen to an increased mutuality of understanding.

The Early Admissions Plan is too new to appraise its effect although it gives promise of reducing multiplicity of applications. At present it would appear that only a very small percentage of candidates is being admitted under this plan, whereas it would appear that as much as a third of a class could be identified and admitted early. Unless the practice can develop to this extent, the additional effort and attention required may prove to be unjustified.

These various developments point to one vital necessity, the provision of more personnel trained in guidance and more adequately staffed admissions offices. Dr. Conant has recommended one counselor for every 250 to 300 high-school students. Most of us are a long way from this ratio. We must work to secure for our schools the quality of guidance they require and in sufficient numbers to meet our increased responsibilities.

\section{Summary of the presentation made by CLYDE VROMAN}

URRENT trends and changes in college admissions policies are basically a reflection of the mounting problems faced by colleges in this period of rapidly growing population. There are 173,000 more students in college this year than there were a year ago. However, this represents an increase of only some 90 students per college in our country, which in itself should not be serious. The crucial problems in college admissions currently are caused by the great tendency of most able students to seek admission to a relatively small group of nationally known prestige colleges which have selective and competitive admissions.

\section{Rising Standaros}

Probably the outstanding trend in college admissions is the raising of admissions standards. In general, this is a gradual change. A survey of 1300 regionally accredited colleges and universities in the United States

Clyde Vroman is Director of Admissions, University of Michigan, Ann Arbor, Michigan. 
showed that approximately one fourth of these institutions had increased their qualitative admission requirements during the past year. Approximately ten per cent of them reported that they had raised their quantitative admission requirements.

\section{Application Fees}

There is a definite trend toward the use of admission application fees. Approximately 53 per cent of the regionally accredited colleges now charge an application fee varying from $\$ 5.00$ to $\$ 25.00$.

\section{Early Decision Plan of Admission}

Probably the most striking development in the admissions programs of colleges with selective admissions is the so-called "early-decision" plan initiated during the past year by a small group of colleges located mainly in the eastern states. This new procedure was designed primarily to reduce the multiple application problem and to remove the pressure of college admissions on excellent students during the last year in high school. Under the "early-decision" plan, the college offers to report its decision on admission in advance to superior candidates on the basis of (1) excellent school records prior to the senior year, (2) high tests scores, (3) strong recommendations from their schools, (4) individual agreements that the college is the candidate's first and only choice of college and that no application will be submitted to another college pending this decision, and (5) the advanced payment of a nonrefundable enrollment deposit to be made usually by February 15 . Most of the colleges which have used this plan have had from 200 to 300 applicants for the early decision and have tended to grant admission to substantially less than one half of those who apply.

Opinion among college admissions officers is divided as to the effects of these early decision plans. They, however, represent at least a sincere and energetic effort to find a solution to the problem of multiple applications and the anxieties of candidates waiting for college decisions. These plans merit the cooperation of everyone during this experimental period.

\section{Admissions Criteria and Factors}

There seems to have been no major change in the criteria for admission used by the colleges. The school record is still considered the most important part of the student's application. Rank in class is still very important, but is going through some transformation as schools develop more differentiation in their instructional programs by such methods as honors courses, multiple track programs, and sectioning of students. As a result, a rank in class without the safeguard of an explanation about the school's curriculum, the method of computing rank, the meaning of special advanced courses, and so forth, is less dependable than formerly as a criterion for admission. However, rank in class is still used a great deal 
and every effort should be made to make it as meaningful as possible, for it is a useful method of comparing the academic records of students within a given high school.

Tests, of course, are playing an increasing role in all phases of admissions. Attitudes toward tests and their use in the college admissions process vary greatly among the several regions of our country. In the East tests are an integral part of the admissions process; in other regions there is much resistance to the use of tests in college admissions. The source of most misunderstandings and concerns is the unwarranted assumption hastily made by many that a test score is the primary factor in the admission decision. I know of no reputable college that bases its admissions action solely on a single test score. On the contrary, it invariably is only one of many factors used in the admissions process.

Most schools use and want to use testing as a part of their instructional and guidance programs; colleges want to use tests for the same sound purposes. Insofar as the colleges must practice selective admission, they find test results indispensable in identifying the most able and qualified students among their applicants. The real problem faced by the colleges is to get uniform and valid measures of the students who wish to be admitted. All colleges, whether or not they practice selective admissions, have the important responsibility of placing their new students properly in courses in which they are likely to succeed. Test results procured in advance help greatly in this process. It is clear that we will have more and not less testing in the immediate future. The new National Defense Education Act includes funds to increase testing and guidance programs. The challenge is to keep undesirable practices and influences to a minimum while we learn how to use testing and guidance more effectively.

School recommendations are playing an increasingly important role in college admissions. Colleges using well-developed admission programs have gone about as far as they can in the use of the school records and test results for admission. There is a definite trend in college admissions to place more emphasis on the student's personal qualities, achievements, motivation, and readiness for college. This trend is caused somewhat by the increasing desire of colleges to keep their student bodies heterogeneous and distributed among the various fields of study and activities on their respective campuses.

\section{School and College Characteristics Sheets}

One of the most promising developments this past year has been the rapid increase in the numbers of colleges issuing descriptive statements of their freshman classes. These statements, sometimes called freshman class profiles, give school counselors and students information on the size and nature of college freshman classes, including qualitative measures, geographic sources of students, financial aids and scholarships awarded, numbers of applications received and the disposition of these applications, 
academic record of recent freshman classes, and information on the college's admissions policies and procedures. About 40 colleges have issued such leaflets and it is hoped that all colleges will prepare such statements.

A similar movement has started in a few high schools which have prepared "school characteristics sheets." Following are some important items which college admissions officers would like to see every high school include in its "school characteristics sheet" and inserted in the application of every student: tunities.

1. Community Characteristics-size, nature, economics, cultural oppor-

2. School system-size, number and kind of high schools, general facts.

3. High school-kind, size, organization, purpose, accreditation; curricula, instructional grouping, honors courses; facilities and library resources; faculty degrees and years of teaching; guidance program, counselors, and number of students per full-time counselor; writing requirements and amount of homework per academic class; graduation requirements; types of diplomas.

4. Senior class-number in class; number taking college preparatory program; number who plan to enter degree-granting institutions; test data on class aptitude and achievement levels; grade distributions and averages.

5. Main colleges and universities attended by seniors in recent years; success and grade-point averages in those institutions.

6. Mechanics-marking system and its interpretation; lowest passing mark and college certifying mark; method of computing class rank; explanations of special courses, quality level, transcript symbols; policies in reporting student records, submitting applications, and making recommendations.

I urge that every high school prepare a "school characteristics sheet" just as soon as possible. This kind of statement has been prepared and used very successfully by such secondary schools as: White Plains, N.Y.; The University of Chicago Laboratory School; The Newman School in New Orleans; Glenbrook School in Northbrook, Ill.; and Evanston Township High School, Evanston, Ill.

The college admission situation in the immediate future will be complex and confusing to many students. If schools and colleges can develop adequate guidance services and processes and maintain good and continuous communication, students will be properly and successfully placed in our 1900 colleges and universities. 